\title{
KAJIAN TEORITIS TENTANG KONSEP RUANG LINGKUP KURIKULUM PENDIDIKAN AGAMA KRISTEN
}

\author{
Imanuel P. Tubulau \\ Sekolah Tinggi Teologi Injili Kejuruan Kupang \\ Korespondensi:ima.tubulau@gmail.com
}

\begin{abstract}
This study aims to analyze the concept of the scope of the curriculum of Christian Religious Education. The method used in this research is descriptive qualitative approach to the study of literature. The results showed that the scope in formulating the Christian Religious Education curriculum considered elements of students, lecturers, educational institutions, institutional leaders, parents of students, churches and community. Understanding the curriculum concept is also an important part in formulating a Christian Religious Education curriculum. With the results of the study found a thesis that a correct understanding of the basic concept of the Christian Religious Education curriculum has a close relationship in the success of the curriculum development process and it's implementation in the context of church service and in the context of general education in school.
\end{abstract}

Keywords: scope, curriculum, christian religious education

\begin{abstract}
Abstrak
Penelitian ini bertujuan untuk menganalisa konsep ruang lingkup kurikulum Pendidikan Agama Kristen. Metode yang digunakan dalam penelitian ini adalah deskriptif kualitatif dengan pendekatan studi kepustakaan. Hasil penelitian menunjukkan bahwa ruang lingkup dalam merumuskan kurikulum Pendidikan Agama Kristen mempertimbangkan unsur mahasiswa, dosen, lembaga pendidikan, pimpinan institusi, orangtua mahasiswa, gereja dan masyarakat. Pemahaman konsep kurikulum juga menjadi bagian penting dalam merumuskan kurikulum Pendidikan Agama Kristen. Dengan hasil penelitian tersebut ditemukan tesis bahwa pemahaman yang benar terhadap konsep dasar kurikulum Pendidikan Agama Kristen memiliki relasi yang erat dalam keberhasilan proses pengembangan kurikulum dan pelaksanaannya dalam konteks pelayanan gereja maupun dalam konteks pendidikan umum di sekolah-sekolah.
\end{abstract}

Kata Kunci: ruang lingkup, kurikulum, pendidikan agama kristen 


\section{Pendahuluan}

Kurikulum merupakan landasan bagi setiap pengelolah pendidikan dalam menentukan setiap arah pengajaran dalam proses pendidikan. Dalam setiap rancangan kurikulum akan berisi berbagai komponan yang saling mengikat serta saling menunjang antara satu komponen dengan komponen yang lain. ${ }^{1}$ Kurikulum juga sering dimaknai sebagai sebagai sebuah dokumen yang terdiri atas berbagai tujuan, bahan kegiatan belajar mengajar, memuat jadwal serta proses evaluasi. ${ }^{2}$ Dengan demikian kurikulum merupakan posisi strategis dalam sebuah proses pendidikan. ${ }^{3}$

Pada hakekatnya kurikulum bersifat dinamis, artinya kurikulum tersebut akan selalu mengalami perubahan dan pengembangan dalam situasi dan kondisi tertentu. Berkaitan dengan kurikulum Pendidikan Kristen, pengajar diharapkan dapat memahami hakekat dari setiap kurikulum itu. ${ }^{4}$ Hal-hal yang menjadi tuntutan secara khusus institusi Pendidikan Agama Kristen dalam melaksanakan perubahan dan pengembangan kurikulum adalah tuntutan bagi kebutuhan gereja dan kebutuhan masyarakat. Untuk mendekatkan dan menyatukan konsep dasar kurikulum pada satu konsep dasar yang benar, maka pembahasan ini hanya akan terfokus kepada ruang lingkup kurikulum Pendidikan Agama Kristen yaitu dengan menganalisa bagaimana konsep dan bentuk kurikulum Pendidikan Agama Kristen di institusi pendidikan.

Penelitian terdahulu yang membahas tentang persoalan kurikulum khususnya pada agama Kristen antara lain yang dilakukan oleh Johanes Hasugian hasil penelitiannya mengungkapkan bahwa kurikulum itu sifatnya antisipatori, oleh karena itu pendidik Kristen harus mampu meminimalisir kegagalan dan meningkatkan keberhasilan dalam pengajaran bagi warga gereja. ${ }^{5}$ Penelitian lain yang dilakukan B. S. Sidjabat membahas khusus tentang Kurikulum Pendidikan Agama Kristen yang berbasis karakter pada perguruan tinggi. ${ }^{6}$ Penelitian ini berbeda dengan penelitian tersebut karena pada kajian ini penulis fokus mencoba menjawab dan merefleksikan ruang lingkup dari kurikulum Pendidikan Agama Kristen.

\section{Metode Penelitian}

Penelitian ini menggunakan metode deskriptif kualitatif. Pendekatan yang digunakan adalah penelitian studi pustaka. Melalui pendekatan ini peneliti akan mengumpulkan sumber-sumber terkait topik penelitian ini melalui buku-buku yang

${ }^{1}$ Ibrahim Nasbi, “Manajemen Kurikulum: Sebuah Kajian Teoritis," Idaarah: Jurnal Manajemen Pendidikan 1, no. 2 (December 18, 2017), accessed June 10, 2020, http://journal.uinalauddin.ac.id/index.php/idaarah/article/view/4274.

${ }^{2}$ Ahmad Saifuddin, "Eksistensi Kurikulum Pesantren Dan Kebijakan Pendidikan," Jurnal Pendidikan Agama Islam (Journal of Islamic Education Studies) 3, no. 1 (2015): 207-234, accessed June 10, 2020, http://jurnalpai.uinsby.ac.id/index.php/jurnalpai/article/view/45.

3Syamsul Bahri, "Pengembangan Kurikulum Dasar Dan Tujuannya," Jurnal Ilmiah Islam Futura 11, no. 1 (February 3, 2017): 15-34, accessed June 10, 2020, https://jurnal.arraniry.ac.id/index.php/islamfutura/article/view/61.

${ }^{4}$ Rinto Hasiholan Hutapea, "Evaluasi Pembelajaran Pendidikan Agama Kristen Pada Kurikulum 2013," Jurnal Ilmiah Religiosity Entity Humanity (JIREH) 1, no. 1 (June 18, 2019): 18-30, accessed June 10, 2020, https://ojs-jireh.org/index.php/jireh/article/view/10.

5Johanes Waldes Hasugian, "Kurikulum Pendidikan Kristen bagi Orang Dewasa di Gereja," KURIOS (Jurnal Teologi dan Pendidikan Agama Kristen) 5, no. 1 (April 30, 2019): 36-53, accessed June 10, 2020, http://www.sttpb.ac.id/e-journal/index.php/kurios/article/view/96.

'Binsen Samuel Sidjabat, "Kerangka Kurikulum Pendidikan Agama Kristen Berbasis Karakter di Perguruan Tinggi," Jurnal Jaffray 17, no. 1 (April 5, 2019): 73-90, accessed June 10, 2020, https://ojs.sttjaffray.ac.id/JJV71/article/view/314. 
memadai. Studi inimenganalisis dokumen-dokumen, baik dokumen tertulis, gambar, hasil karya, maupun elektronik. ${ }^{7}$ Kemudian dilakukan analisis dengan membuat gambarangambaran rinci mengenai data sosial yang ditemukan di lapangan kemudian dibuat beberapa kesimpulan sementara. ${ }^{8}$ Sumber-sumber tersebut menjadi dasar dalam menyusun konsep penulisan. Dari konsep-konsep yang ada akan dianalisa dan disusun secara sistematis untuk mendapatkan kesimpulan dari penelitian ini.

\section{Hasil dan Pembahasan}

\section{Hakikat Pendidikan Agama Kristen}

Pengertian Pendidikan Agama Kristen atau Pendidikan Kristen begitu banyak dijelaskan dari berbagai refrensi sebelumnya, yang intinya adalah proses pengubahan sikap dan tingkah laku seseorang atau kelompok orang dalam usaha mendewasakan manusia melalui upaya pengajaran dan pelatihan berdasarkan ajaran-ajaran Kristen yang sesaui dengan kebenaran-kebenatana firman Tuhan. Definisi pendidikan Kristen sebagai mana dirumuskan oleh Robert W. Pazmino dalam bukunya Foundationnal Issues In Christion Education (1988), yang dikutip oleh B. Samuel Sidjabat, sebagai berikut: Pendidikan Kristen merupakan upaya ilahi dan manusiawi dilakukan secara bersahaja dan berkesinambungan, untuk memberikan pengetahuan, nilai-nilai,sikap-sikap, keterampilan, sensitifitas, tingkah laku yang konsisten dengan imanKristen.

Pendidikan mengupayakan perubahan, pembaharuan dan reformasipribadi-pribadi, kelompok dan struktur oleh kuasa Roh Kudus, sehinggabersusuaian dengan kehendak Allah sebagai mana dikatakan dalam Kitab Suci. Terutama dalam Yesus Kristus, serta diwujudkan dalam kehidupan sehari-hari. Selanjutnya Homrighousen dan Enklaar dalam bukunya Pendidikan Agama Kristen menguraikan makna Pendidikan Agama Kristen sebagai berikut: arti yang sedalam-dalamnya dari PAK, bahwa dengan menerima pendidikan itu segala pelajar, muda dan tua, memasuki persekutuan iman yang hidup dengan Tuhan sendiri dan oleh dan di dalam Dia mereka dekatpada persekutuan serta persekutuan jemaat-Nya yang mengakui dan mempernuliakan nama-Nya di segala waktu dan tempat. Kemudian Daniel Nuhamara, memberikan penjelasan terhadap makna Pendidikan Agama Kristen dari segi elemen intinya antara lain: Pertama, harus dikatakan bahwa PAK itu adalah suatu usaha pendidikan. Ini tak berarti bahwa pendidikan hanya terbatas pada pendidikan yang formal baik di sekolah atau di dalam gereja, melainkan juga pendidikan yang dilakukan dengan pendekatan sosialisasi asalkan sosialisasi tersebut disengaja. Kedua, PAK juga merupakan pendidikan yang khusus yakni dalam dimensi religius manusia. Artinya segala pendidikan yang dikhususkan pada dimensi religious manusia, apakah itu pencarian akan yang transenden, kehendak-Nya dan pem-berlakuan kehendak-Nya dalam kehidupan konkrit. Ketiga, secara khusus PAK menunjuk kepada persekutuan iman yang melakukan tugas pendidikan agamawi, yakni persekutuan iman Kristen. Karenanya pencarian manusia terhadap yang transenden serta ekspresi dari hubungan itu diwarnai oleh ajaran Kristen sebagai mana dinyatakan dalam Alkitab sebagai warisan. Keempat, PAK sebagai usaha pendidikan bagaimana pun juga mempunyai hakikat politis. Artinya, PAK tidak hanya ada intervensi dalam kehidupan individual seseorang di bidang kerohaniannya saja, tetapi juga

\footnotetext{
${ }^{7}$ Natalina Nilamsari, “Memahami Studi Dokumen Dalam Penelitian Kualitatif," Wacana XII, no. 2 (June 2014): 177-181.

${ }^{8}$ Ezra Tari and Rinto Hasiholan Hutapea, "Peran Guru Dalam Pengembangan Peserta Didik

Di Era Digital" 1, no. 1 (2020): 1-13,

http://jurnalsttkharisma.ac.id/index.php/Kharis/article/view/1.
} 
mempengaruhi cara dan sikap mereka ketika menjalani kehidupan dalam konteks masyarakatnya. ${ }^{9}$

Dari kutipan-kutipan di atas, maka dapat disimpulkan bahwa Pendidikan Agama Kristen merupakan proses pengajaran dan pembelajaran yang bersumber pada Alkitab dan berpusat pada Yesus Kristus serta di bawah tuntunan kuasa Roh Kudus yang membimbing orang percaya pada semua tingkat umur dan dalam segala aspek kehidupannya bagi pertumbuhan iman dan pengenalan akan Kristus serta memperlengkapi mereka bagi pelayanan pemberitaan Injil menuju kepada kedewasaan dalam Kristus serta kemuliaan bagi Allah.

\section{Kurikulum Pendidikan Agama Kristen Pengertian Kurikulum}

Pengertian kurikulum dapat didefinisikan dari tiga aspek yaitu aspek etimologis, terminologis, dan dogmatis (teologis). Aspek etimologis berkaitan dengan asal-usul kata, terminologis berhubungan dengan pengertian kurikulum dalam dunia pendidikan dan dogmatis adalah pengertian kurikulum dalam pandangan iman Kristen dan alkitabiah. Pengertian kurikulum dari ketiga aspek tersebut dapat dijelaskan berikut ini. Pertama, pengertian kurikulum secara etimologis. Ditinjau dari asal-usul kata atau pengertian secara etimologis, para pakar kurikulum sependapat bahwa: kata "kurikulum"(curriculum) berasal dari bahasa Latin yaitu curi, yang artinya pelari, dan curere yang artinya tempat berpacu. Jadi istilah kurikulum diambil dari dunia atletik, yang mengandung pengertian suatu jarak yang harus ditempuh oleh pelari dari garis start sampai garis finish. ${ }^{10}$ Jadi istilah kurikulum dipinjam dari bahasa Latin, menunjuk pada suatu jarak tertentu yang harus ditempuh oleh para atlet dalam rangka perebutan hadiah atau prestasidalam dunia keolahragaan.

Kedua, pengertian kurikulum secara terminologi. Secara terminologi yakni istilah kurikulum yang digunakan dalam dunia pendidikan mempunyai dua pandangan, tradisional dan moderen. Dalam pandangan tradisional,"Kurikulum adalah sejumlah pengetahuan atau pelajaran yang harus ditempuh atau diselesaikan siswa guna mencapai suatu tingkat atau ijazah."11 S. Nasution dalam bukunya Asas-Asas Kurikulum, lebih lanjut mengungkapkan bahwa, kurikulum yang digunakan dalam pendidikan dan pembelajaran, yakni sejumlah mata pelajaran di sekolah atau mata kuliah di perguruan tinggi, yang harus ditempuh untuk mencapai suatu ijazah atau tingkat. Kurikulum juga berarti keseluruhan pelajaran yang disajikan oleh suatu lembaga pedidikan. Jadi, dalam pandangan tradisional, pengertian kurikulum dipahami sebatas pada sejumlah pengetahuan atau mata pelajaran yang direncanakan oleh pihak sekolah, yang harus diselesaikan siswa untuk memperoleh ijazah atau kenaikan kelas, sehingga pandangan ini dianggap sempit dalam penafsiran ahli kurikulum pendidikan moderen.

Dalam pandangan moderen, kurikulum didefinisikan dalam pengertian yang luas, yang mengacu pada keseluruhan program pendidikan dan pengajaran yang direncanakan di sekolah-sekolah, baik kegiatan kurikuler maupun ekstrakurikuler untuk mencapai tujuan pendidikan. Adapun Peraturan Menteri Pendidikan dan Kebudayaan Nomor 73 Tahun 2013 dalam Pasal 2 menyatakan tentang Kerangka Kualifikasi Nasional Indonesia (KKNI) yaitu kerangka penjenjangan kualifikasi yang dapat menyandingkan, menyetarakan, dan

\footnotetext{
${ }^{9}$ Daniel Nuhamara, Pembimbing Pendisikan Agama Kristen (Bandung: Jurnal Info Media, 2002), 25-26.

10Sudirman N, Ilmu Pendidikan (Bandung: Remadaja Karya, 1987), 9.

${ }^{11} \mathrm{~N}$, Ilmu Pendidikan.
} 
mengintegrasikan capaian pembelajaran dari jalur pendidikan nonformal, pendidikan informal, dan/atau pengalaman kerja ke dalam jenis dan jenjang pendidikan tinggi.

Berdasarkan beberapa pengertian di atas, maka yang dimaksud dengan kurikulum adalah keseluruhan program penyelenggaraan pendidikan dan pengajaran yang direncanakan secara sengaja dan sistematis oleh setiap lembaga pendidikan untuk dipakai sebagai pedoman atau petunjuk pelaksanaan kegiatan mengajar belajar di sekolah bagi pencapaian tujuan pendidikan. Pada tingkat perguruan tinggi, kurikulum merupakan seluruh program perkuliahan, baik kegiatan sekuler maupun ekstrakurikuler yang dibukukan lembaga pendidikan sebagai pedoman pelaksanaan perkuliahan.

Ketiga, pengertian kurikulum secara dogmatis. Dalam pandangan teologis atau dogmatis, para pakar Pendidikan Agama Kristen mengakui Alkitab sebagai kurikulum tertulis. Asumsi ini bertolak dari anggapan bahwa Alkitab adalah catatan isi hati, karya, rencana dan perjanjian-perjanjian yang telah, sedang dan akan dilakukan Allah terhadap umat-Nya dan apa yang harus ditaati, dipegang dan dilakukan oleh umat-Nya untuk memenuhi maksud dan kehendak Allah. Setiap pribadi yang melakukan kehendak Allah dalam kehidupan sehari-hari merupakan tujuan dari kurikulum Kristen. Karena itu, kurikulum dapat dianggap sebagai pengalaman yang dibimbing. Kurikulum Kristen mencakup unsur-unsur penginjilan, pengajaran, penyembahan, dan persekutuan.

Dalam pandangan iman Kristen (dogmatis), kurikulum menyangkut program penginjilan, kesaksian, pengajaran, penyembahan, dan persekutuan yang direncanakan umat Allah untuk dilaksanakan bagi kemuliaan Allah dalam kehidupannya. Dengan demikian dalam iman Kristen, Alkitab diakui sebagai kurikulum Allah, dimana di dalamnya dimuat catatan isi hati, kehendak, karya, hukum, mandat atau perintah yang ditetapkan dan diberikan Allah kepada umat-Nya untuk diterima, dipegang, direnungkan, ditaati, dan diajarkan dari generasi ke generasi untuk memenuhi maksud dan kehendak Allah.

\section{Fungsi Kurikulum Pendidikan Agama Kristen}

Dalam sistem PendidikanAgama Kristen, kurikulum sangat berfungsi bagi kelompok pelaku perubahan pendidikan, yaitu mahasiswa, dosen, institusi, unsur pemimpin lembaga pendidikan, orang tua mahasiswa dan masyarakat. Manfaat kurikulum bagi pihak-pihak tersebut ialah sebagai berikut: pertama, bagi peserta didik dan mahasiswa. Bagi peserta didik atau mahasiswa, kurikulum berfungsi sebagai alat komunikasi dalam proses belajar mengajar. Slameto dalam bukunya Proses Belajar Mengajar Dalam Sistem Kredit Semester menyatakan bahwa, kurikulum sebagai organisasi berlajar tersusun yang disiapkan untuk mahasiswa sebagai salah satu konsumsi pendidikan mereka. Dengan ini maka diharapkan mereka akan mendapat pengalaman baru yang kelak kemudian dapat dikembangkan seirama dengan perkembangannya, guna melengkapi bekal hidupnya. Dengan demikian, fungsi kurikulum bagi peserta didik adalah sebagai organisasi belajar yang dikomunikasikan oleh lembaga pendidikan untuk ditindaklanjuti sebagai alat petunjuk dalam proses belajar mengajar, dalam pengembangan dirinya.

Kedua, bagi dosen. Dosen sebagai pihak yang yang terlibat langsung dalam setiap proses pendidikan ${ }^{12}$ diharapkan dapat memahami tentang fungsi kurikulum sebagai pedoman pelaksanaan kegiatan mengajar pada sekolah. Hal senada dikemukakan oleh Slameto. Ia mengungkapkan bahwa bagi dosen kurikulum berfungsi sebagai: (1) Pedoman kerja dalam menyusun dan mengorganisir pengalaman belajar para mahasiswa dan (2) Pedoman untuk megadakan evaluasi terhadap perkembangan mahasiswa dalam rangka

12Marsi Bombongan Rantesalu, GURU PENDIDIKAN AGAMA KRISTEN SEBAGAI PELOPOR REVOLUSI MENTAL, preprint (AgriXiv, October 14, 2019), accessed January 21, 2020, https://osf.io/576qt. 
menyerap sejumlah pengalaman yang diberikan. ${ }^{13}$ Mengacu pada gagasan tersebut, fungsi kurikulum bagi dosen atau pengajar ialah sebagai pedoman perencanaan program pengajaran dalam perkuliahan dan sebagai barometer untuk mengukur hasil belajar mahasiswa dalam pencapaian tujuan pengajaran.

Selain itu, panggilan dosen dalam sebuah kurikulum bukan hanya mengelola perkuliahan PAK untuk mengajarkan iman Kristen berdasarkan pokok bahasan Tuhan Yang Maha Esa, Manusia, Hukum, Moral, Ilmu pengetahuan, Teknologi dan Seni (IPTEKS); Kerukunan antar umat beragama, Masyarakat, Budaya, dan Politik, tetapi juga mengembangkan kepribadian dengan memfasilitasi terjadinya transformasi karakter mahasiswa supayamereka menjadi lulusan yang jujur, cerdas, tangguh dan peduli. ${ }^{14}$ Dengan demikian, dosen memiliki peran penting dalam penyusunan dan implementasi dari kurikulum di Perguruan Tinggi.

Ketiga, bagi lembaga pendidikan. Bagi lembaga pendidikan bersangkutan, kurikulum berfungsi sebagai alat untuk mencapai tujuan pendidikan, baik tujuan institusional, kurikuler, dan instruksional. Fungsi ini dijelaskan Sudirman N., dkk. Yang menjelaskan fungsi kurikulum dalam pendidikan tidak lain merupakan alat untuk mencapai tujuan pendidikan. ${ }^{15}$ Pernyataan tersebut ditegaskan kembali oleh Burhan Nurgiyantoro, yaitu fungsi kurikulum bagi sekolah yang bersangkutan paling tidak dapat berfungsi sebagai alat untuk mencapai tujuan-tujuan pendidikan yang diinginkan, serta kurikulum dijadikan sebagai pedoman untuk mengatur kegiatan-kegiatan pendidikan yang dilaksanakan di sekolah. ${ }^{16}$ Bagi setiap lembaga pendidikan, fungsi kurikulum amat penting. Kurikulum bagaikan kompas yang dapat menentukan arah perencanaan, pelaksanaan, penilaian dan perbaikan program pendidikan dan pengajaran di sekolah. Selain itu, kurikulum bermakna penting bagi institusi pendidikan yang lebih tinggi, guna mengontrol dan memelihara keseimbangan terhadap proses pembelajaran.

Keempat, bagi unsur pimpinan institusi. Bagi pemimpin dan unsur pemimpin dalam suatu lembaga pendidikan, misalnya Rektor, Pembantu Rektor (Purek) I, Pembantu Rektor (Purek) II, Pembantu Rektor (Purek) III pada tingkatan Universitas atau Institut. Ketua, Pembantu Ketua (Puket) I, Pembantu Ketua (Puket) II, Pembantu Ketua (Puket) III, pada tingkatan sekolah tinggi atau akademi, kepala sekolah pada tingkatan sekolah dasar dan menengah, kurikulum sangat penting dalam hubungannya dengan tugas dan tanggung jawab yang dijalankannya.

Hal tersebut dipertegas kembali oleh Slameto dan menjelaskan bahwa fungsi kurikulum bagi rektor dan pembantu rektor I atau dekan dan pudek I ialah: (1) Sebagai pedoman dalam mengadakan fungsi supervisi yaitu memperbaiki situasi belajar. (2) Sebagai pedoman dalam melaksanakan fungsi supervisi dalam menciptakan situasi untuk menunjang situasi belajar mahasiswa ke arah yang lebih baik. (3) Sebagai pedoman dalam melaksanakan fungsi supervisi dalam memberikan bantuan kepada dosen untuk memperbaiki situasi belajar. (4) Sebagai pedoman untuk mengembangkan kurikulum lebih lanjut. (5) Sebagai pedoman untuk mengadakan evaluasi kemajuan belajar mengajar. ${ }^{17}$

${ }^{13} \mathrm{~N}$, Ilmu Pendidikan.

${ }^{14}$ Binsen Samuel Sidjabat, "Kerangka Kurikulum Pendidikan Agama Kristen Berbasis Karakter Di Perguruan Tinggi Character-Based Christian Religious Education Curriculum Framework in Higher Education," Jurnal Jaffray 17, no. 1 (2019): 73-90.

15Ibid., 23.

16Burhan Nurgiyantoro, Dasar-Dasar Pengembangan Kurikulum Sekolah (Yogyakarta: BPFE, 1998), 6.

17Slameto, Proses Belajar Mengajar Dalam Sistem Kredit Semester (Jakarta: Bumi Aksara, 1991), 5. 
Kelima, bagi orangtua mahasiswa. Kurikulum tidak hanya berguna bagi subyek pendidikan, tetapi bermanfaat bagi orang tua juga. Hendyat Soetopo dan Wasty Soemanto menyatakan, bagi orang tua murid kurikulum juga mempunyai fungsi yaitu agar orang tua dapat turut serta membantu usaha sekolah dalam memajukan putra-putrinya. Bantuan orang tua dalam memajukan pendidikan ini dapat melalui konsultasi langsung dengan sekolah tentang masalah-masalah yang menyangkut anak-anaknya. ${ }^{18}$ Bagi orang tua mahasiswa, kurikulum sebagai alat komunikasi dan motivasi untuk turut berpartisipasi dalam penyelenggaraan pendidikan, khususnya dalam hal memberikan dukungan moril dan materil kepada mahasiswa atau peserta didiknya dan juga kepada pihak lembaga pendidikan dalam memajukan lembaga pendidikan bersangkutan.

Keenam, bagi gereja dan masyarakat. Kurikulum yang diterapkan di suatu sekolah sangat berguna bagi gereja dan masyarakat yang ada di sekitarnya. Pentingnya kurikulum bagi masyarakat dikemukakan oleh Hindyat Soetopo, bahwa dengan mengetahui kurikulum perguruan tinggi, masyarakat atau pemakai lulusan dapat melakukan sekurang-kurangnya dua hal, yaitu ikut memberikan bantuan guna memperlancar pelaksanaan program pendidikan yang membutuhkan kerja sama dengan pihak masyarakat, serta ikut memberikan kritik/saran yang membangun dalam rangka menyempurnakan program pendidikan di perguruan tinggi agar lebih serasi dengan kebutuhan masyarakat di lapangan kerja. ${ }^{19}$ Bagi gereja dan masyarakat sebagai pihak yang akan menerima dan memakai para lulusan, kurikulum berfungsi sebagai media informasi, komunikasi dan motivasi bagi pemberian dukungan kepada pihak lembaga pendidikan dan akan menjadi daya tarik serta minat anggota masyarakat untuk mengikuti program pendidikan pada lembaga pendidikan bersangkutan.

Berdasarkan pada beberapa penjelasan di atas dapat ditarik kesimpulan. Kurikulum memegang peranan yang amat penting dan sangat berfungsi dalam dunia pendidikan. Kurikulum merupakan alat kunci pencapaian tujuan pendidikan, petunjuk belajar, panduan perencanaan pendidikan, pedoman penyelenggaraan pengajaran, dan pelaksanaan evaluasi hasil belajar serta sebagai acuan bagi pelaksanaan fungsi supervisi pendidikan.

\section{Komponen-Komponen Kurikulum}

Dalam sistem pendidikan, kurikulum merupakan suatu sistem yang terdiri dari beberapa komponen yang saling berkaitan erat dan saling kerja sama antara satu dengan yang lainnya secara fungsional. Komponen-komponen itu menurut Sri P. I. Subekti terdiri dari: komponen tujuan, isi materi, organisasi mata pelajaran, strategi pembelajaran sarana dan evaluasi. ${ }^{20}$ Pendapat yang sama juga dikemukakan oleh Nama Syaodih. Ia menjelaskan komponen-komponen dari anatomi tubuh kurikulum yang utama adalah tujuan, isi materi, proses atau sistem penyampaian dan media, serta evaluasi. Keempat komponen tersebut berkaitan erat satu sama lain. ${ }^{21}$

Melihat dari beberapa penjelasan tersebut, komponen-komponen kurikulum dapat diuraikan sebagai berikut. Pertama, komponen tujuan. Kurikulum adalah suatu program yang bertujuan untuk mencapai sejumlah tujuan pendidikan dan tujuan itulah dijadikan arah bagi seluruh kegiatan kependidikan yang dijalankan. Keberhasilan pelaksanaan program pengajaran pada suatu institusi pendidikan sangat ditentukan dari seberapa jauh

\footnotetext{
${ }^{18}$ Hendyat Soetopo and Wasti Soemanto, Pembinaan Dan Pembangunan Kurikulum (Jakarta: Bina Aksara, 1986), 19.

19Ibid., 21.

${ }^{20}$ Sri Purnami I. Subekti, Kurikulum (Jakarta: Guna Widia, 1995), 20.

${ }^{21}$ Nana Syaodih Sukmadinata, Pengembangan Kurikulum Teori Dan Praktek (Bandung: Remaja Rosdakarya, 2000), 103.
} 
pencapaian tujuan-tujuan tersebut. Dalam setiap kurikulum sekolah, telah dicantumkan tujuan-tujuan pendidikan yang akan dicapai oleh institusi pendidikan yang bersangkutan. Hendyat Soetopo berpendapat, ada dua tujuan yang dapat ditemukan dalam suatu kurikulum sekolah yaitu, tujuan yang ingin dicapai oleh sekolah secara keseluruhan dan tujuan yang hendak dicapai oleh setiap bidang studi. ${ }^{22}$

Tujuan yang ingin dicapai sekolah secara keseluruhan atau disebut dengan tujuan institusional yaitu tujuan yang mencakup aspek: pengetahuan, keterampilan, sikap, dan nilai-nilai yang diharapkan dimiliki oleh para lulusan lembaga pendidikan bersangkutan. ${ }^{23}$ Tujuan yang ingin dicapai dalam setiap bidang studi (mata pelajaran atau mata kuliah) yaitu penjabaran dari capaian pembelajaran yang meliputi tujuan kurikuler dan tujuan instruksional yang terdapat dalam setiap Rencana Pembelajaran semester (RPS) tiap mata kuliah. ${ }^{24}$ Kedua tujuan ini juga mencakup: aspek pengetahuan, keterampilan, dan sikap serta nilai-nilai yang diharapkan dimiliki mahasiswa setelah mempelajari tiap mata kuliah dan pokok bahasan dalam proses perkuliahan. ${ }^{25}$

Kedua, komponen isi materi. Komponen isi materi kurikulum mencakup isi kurikulum dan struktur kurikulum. Isi kurikulum meliputi jenis-jenis bidang studi yang diajarkan dan isi program dari masing-masing bidang studi atau mata kuliah. Menurut Burhan Nurgiyantoro, isi kurikulum ini meliputi jenis-jenis bidang studi yang diajarkan dan isi program masing-masing bidang studi tersebut. ${ }^{26}$ Kemudian Sri Purnami Subekti dalam bukunya Kurikulum juga menegaskan bahwa isi kurikulum dapat berupa pokok-pokok bahasan dan sub-sub pokok bahasan dari setiap mata kuliah. ${ }^{27}$ Pada umumnya isi materi pembelajaran telah dijabarkan pada Garis Besar Program Pembelajaran (GBPP) dan silabus (kontrak pembelajaran). Silabus merupakan suatu susunan garis besar program pembelajaran yang meliputi garis besar materi kuliah, metodologi penyajian, pengalokasian waktu penyajian, sumber bahan dan teknik penilaian yang diterapkan atau digunakan.

Ketiga, komponen organisasi kurikulum. Di samping tujuan dan isi materi, setiap kurikulum terdapat unsur organisasi. Organisasi kurikulum yang dimaksud adalah struktur program kurikulum dalam bentuk kerangka umum dari program-program perkuliahan yang siap disampaikan kepada peserta didik (siswa atau mahasiswa). Sri Purnami Subekti lebih lanjut berpendapat pengorganisasian mata pelajaran mengenal dua macam struktur yaitu pengorganisasian berstruktur horizontal dan berstruktur vertikal. ${ }^{28}$ Yang dimaksud dengan struktur kurikulum horizontal adalah pengorganisasian mata pelajaran secara terpisah-pisah antara mata kuliah atau mata pelajaran yang satu dengan mata kuliah atau mata pelajaran yang lain. Dalam struktur ini, perencanaan dan penyajian mata kuliah atau mata pelajaran dilakukan melalui beberapa bentuk yaitu: penyusunan mata pelajaran secara terpisah-pisah (separate subject), kelompok-kelompok mata pelajaran (correlated), penyatuan seluruh pelajaran (integrated). ${ }^{29}$ Sedangkan struktur kurikulum vertikal adalah penyusunan mata kuliah atau mata pelajaran sesuai dengan tingkatan kelas, tingkat semester dan tingkat pendidikan. Misalnya, mata pelajaran agama untuk kelas I, II, III, IV, V dan VI untuk tingkat

22Soetopo and Soemanto, Pembinaan Dan Pembangunan Kurikulum, 26.

${ }^{23}$ Soetopo and Soemanto, Pembinaan Dan Pembangunan Kurikulum.

${ }^{24}$ Leryani Mince Maria Manuain, Ferdinant Alexander, and Marsi Bombongan Rantesalu, "Pengaruh Model Pembelajaran Jigsaw Terhadap Peningkatan Hasil Belajar Sejarah Pendidikan Agama Kristen," Ciencias $\square$ : Jurnal Penelitian dan Pengembangan Pendidikan 1, no. 1 (July 27, 2018): 1-12, accessed June 10, 2020, https:// ejournal.upg45ntt.ac.id/ciencias/article/view/9.

${ }^{25}$ Soetopo and Soemanto, Pembinaan Dan Pembangunan Kurikulum.

${ }^{26}$ Nurgiyantoro, Dasar-Dasar Pengembangan Kurikulum Sekolah, 10.

27Purnami I. Subekti, Kurikulum, 20.

28Purnami I. Subekti, Kurikulum.

${ }^{29}$ Nurgiyantoro, Dasar-Dasar Pengembangan Kurikulum Sekolah, 11. 
pendidikan dasar dan menengah, dan mata kuliah untuk semester I, II, III, IV dan seterusnya bagi tingkat pendidikan universitas atau perguruan tinggi.

Keempat, komponen strategi. Strategi adalah cara atau tehnik yang digunakan dalam pelaksanaan pengajaran, penilaian, pengadaan bimbingan dan konseling, pengaturan kegiatan kampus secara keseluruhan, pemilihan metode kuliah, alat dan sumber yang digunakan. Semua strategi yang digunakan dalam pelaksanaan pendidikan pada suatu lembaga pendidikan adalah untuk mencapai tujuan pendidikan yang merupakan bagian penting dari tubuh kurikulum. Universitas-universitas seperti pada negara-negara maju, strategi pembelajaran atau penyajian suatu mata kuliah atau mata pelajaran sudah secara langsung termuat dalam silabus atau kontrak pembelajaran.

Kelima, komponen evaluasi. Evaluasi pengajaran merupakan salah satu bagian dari komponen kurikulum. Komponen evaluasi ini mencakup rencana dan cara penilaian yang ditetapkan (direncanakan) atas pelaksanaan keseluruhan kegiatan belajar mengajar. Bentukbentuk alat evaluasi yang biasa dimuat dalam sebuah kurikulum adalah bentuk subjektif dan objektif. Bentuk subjektif adalah alat evaluasi yang disiapkan dalam bentuk pertanyaanpertanyaan dengan memakai kata-kata operasional antara lain menjelaskan, menjabarkan, menggambarkan, dan menyebutkan. Bentuk objektif adalah alat evaluasi yang disiapkan dalam bentuk pilihan ganda, menjodohkan, dan benar-salah.

\section{Tujuan Kurikulum Pendidikan Agama Kristen}

Kurikulum merupakan suatu alat yang sangat memegang peranan penting bagi pencapaian tujuan pendidikan, secara khusus pendidikan agama (agama Kristen). Tujuan pendidikan agama Kristen itu sendiri terdiri dari lima tingkatan yaitu tujuan universal (terminal), tujuan nasional, tujuan institusi, tujuan kurikuler, dan tujuan instruksional. Masing-masing tujuan tersebut, tergambar dalam paparan berikut. Pertama, tujuan terminal. Tujuan terminal atau universal dari penyelenggaraan pendidikan dan pengajaran agama Kristen adalah untuk melaksanakan Amanat Agung Yesus Kristus yaitu untuk menjadikan semua bangsa di dunia ini menjadi murid Kristus (Matius 28:18). Lebih lanjut B. Samuel Sidjabat menguraikan, sasaran akhir dari seluruh upaya pendidik dalam mengajarkan iman Kristen ialah membimbing, menuntun, memberi pengarahan dan dorongan bagi individu dan kelompok sedemikian rupa sehingga mereka menyadari dan menjalani panggilan hidupnya dalam kerangka menjadi murid Kristus (Mat 28:18). Jadi, sasaran atau tujuan tertinggi dari setiap kegiatan belajar mengajar yang dikelola haruslah membawa dan mendorong peserta didik untuk lebih banyak mengenal Allah. ${ }^{30}$ Proses pemuridan ini dilakukan melalui penginjilan, pembaptisan, pengajaran, pembimbingan dan penyuluhan kepada semua bangsa dan suku bangsa dengan tujuan agar mereka dapat mengenal dan menerima Kristus sebagai Tuhan dan Juruselamat, menyerahkan hidup kepada Kristus dan melakukan segala sesuatu yang telah diperintahkan-Nya, serta turut berpartisipasi aktif dalam pelayanan dan mampu untuk bertanggung jawab atas panggilannya itu.

Kedua, tujuan Pendidikan Nasional. Pendidikan Agama Kristen merupakan bagian integral dari pendidikan nasional. Dalam konteks ini, tujuan pelaksanaan pendidikan Kristen adalah untuk berpartisipasi aktif dalam meningkatkan kualitas sumber daya manusia Indonesia secara utuh. Weinata Sairin menegaskan, tujuan pendidikan Kristen di Indonesia adalah mencerdaskan kehidupan bangsa dan mengembangkan manusia Indonesia seutuhnya, yaitu manusia yang beriman dan bertaqwa kepada Tuhan Yang Maha Esa dan berbudi pekerti luhur, memiliki pengetahuan dan keterampilan, kesehatan jasmani dan rohani, kepribadian yang mantap dan mandiri serta rasa tanggung jawab kemasyarakatan 2000), 68-69.

${ }^{30}$ B.S. Sidjabat, Menjadi Guru Profesional Sebuah Presfektif Kristen (Bandung: Kalam Hidup, 
dan kebangsaan. $^{31}$ Dengan demikian, peranan, fungsi dan tujuan pelaksanaan dari pendidikan Kristen adalah untuk membentuk manusia Indonesia secara holistik, baik secara fisik, mental, sosial, emosional, moral, dan spiritual. Untuk mencapai tujuan inilah kurikulum dirancang dan diterapkan dalam setiap lembaga pendidikan Kristen.

Ketiga, tujuan institusional. Tujuan institusional adalah tujuan yang hendak dicapai oleh setiap jenis dan jenjang lembaga pendidikan Kristen, seperti tujuan sekolah dasar, sekolah menengah pertama, sekolah menengah atas dan perguruan tinggi. Tiap jenjang lembaga pendidikan Kristen memiliki tujuannya masing-masing sesuai visi dan misi yang dijalankannya. Bagi lembaga pendidikan teologi, tujuannya adalah untuk menyiapkan para gembala atau pelayan umat, penginjil dan pengajar yang berperan untuk melayani, memperlengkapi dan mengisi kebutuhan orang-orang kudus dalam jemaat sehingga mereka dapat membangun tubuh Kristus yang bertumbuh dalam iman dan bertambah dalam pengetahuan yang benar tentang Yesus Kristus; menjadi dewasa menuju kepada kesempurnaan Kristus (Efesus 4:12-15).

Keempat, tujuan kurikuler. Tujuan kurikuler adalah tujuan yang hendak dicapai melalui suatu program studi, bidang studi, jurusan dan mata kuliah. Dalam konteks ini Slameto berpendapat bahwa tujuan yang akan dicapai oleh atau melalui tiap bidang studi disebut tujuan kurikuler. Tujuan ini tertuang dalam GBPP (Garis Besar Program Pengajaran) tiap bidang studi. ${ }^{32}$ Selanjutnya dapat dicontohkan sebagai berikut: tujuan mata kuliah Psikologi Perkembangan ialah supaya mahasiswa memahami perkembangan psikologi individu sejak prenatal sampai kepada usia lanjut menyangkut ciri-ciri perkembangan, tahap perkembangan dan faktor-faktor yang mempengaruhi perkembangan psikologisnya.

Kelima, tujuan instruksional. Tujuan instruksional adalah tujuan yang hendak dicapai setelah menyelesaikan suatu proses pembelajaran. Sudirman N., dkk., menandaskan bahwa tujuan instruksional berkenaan dengan tujuan setiap pertemuan. Artinya, kemampuan-kemampuan yang diharapkan dimiliki siswa setelah ia menyelesaikan pengalaman belajar suatu pertemuan. ${ }^{33}$ Dalam operasionalnya, tujuan pembelajaran dapat dirumuskan ke dalam dua bentuk yaitu bentuk Tujuan Instrusional Umum (TIU) dan Tujuan Instrusioal Khusus (TIK). Perbedaan dari kedua tujuan ini terletak pada penggunaan kata kerja dalam perumusan tujuan. Tujuan instrusional umum dirumuskan dalam kata-kata dan tingkah laku yang bersifat umum dan tujuan instruksional khusus dirumuskan dalam kata-kata dan tingkah laku yang khusus.

Dalam perumusan tujuan instruksional umum dan khusus, umumnya dikelompokkan ke dalam tiga ranah yaitu ranah tujuan kognitif, ranah tujuan afektif, dan ranah tujuan psikomotoris. Menurut Mohamad Uzer Usman, tujuan isntruksional pada umumnya dikelompokkan ke dalam tiga kategori, yakni domain kognitif, efektif, dan psikomotor. Domain kognitif mencakup tujuan yang berhubungan dengan ingatan, pengetahuan, dan kemampuan intelektual. Domain afektif mencakup tujuan yang berhubungan dengan perubahan-perubahan sikap, nilai, perasaan, dan minat. Domain psikomotor mencakup tujuan-tujuan yang berhubungan dengan manipulasi dan kemampuan gerak. ${ }^{34}$

Dengan demikian, sesuai dengan tingkatannya, kurikulum Pendidikan Agama Kristen mempunyai tujuan universal, nasional, institusional atau kelembagaan, kurikuler

${ }^{31}$ Weinata Sairin, Partisipasi Kristen Dalam Pembangunan Pendidikan Di Indonesia (Jakarta: BPK Gunung Mulia, 1998), 1.

${ }^{32}$ Proses Belajar Mengajar Dalam Sistem Kredit Semester, 4.

${ }^{33} \mathrm{~N}$, Ilmu Pendidikan, 18.

${ }^{34}$ Moh. Uzer Usman, Menjadi Guru Profesional (Bandung: Remaja Rosdakarya, 1991), 29. 
dan instruksional. Kurikulum Pendidikan Agama Kristen direncanakan dan diterapkan untuk mencapai tujuan universal, nasional, institusional, kurikuler, dan instruksional.

\section{Kesimpulan}

Kurikulum adalah seperangkat rencana dan program pendidikan atau pengajaran yang direncanakan oleh lembaga atau institusi pendidikan untuk digunakan sebagai arah dan pedoman dari pelaksanaan kegiatan belajar mengajar bagi pencapaian tujuan pendidikan. Dalam pendidikan Kristen, kurikulum sangat penting dan berfungsi bagi peserta didik (siswa atau mahasiswa), dosen, lembaga pendidikan, unsur pemimpin lembaga, orang tua, gereja dan masyarakat yang berperan sebagai alat pencapaian tujuan pendidikan, petunjuk belajar, pedoman penyelenggaraan pengajaran dan sebagai alat komunikasi dan informasi. Komponen-komponen kurikulum adalah tujuan, isi materi, organisasi kurikulum, strategi, dan evaluasi kurikulum. Tujuan utama dari proses perencanaan dan pelaksanaan kurikulum Pendidikan Agama Kristen adalah untuk menjadikan semua orang murid Kristus, membentuk manusia Indonesia secara utuh, membina pembina atau pengajar umat dan peserta didik memperoleh perubahan hidup.

Hasil penelitian juga menunjukkan bahwa ruang lingkup dalam merumuskan kurikulum Pendidikan Agama Kristen mempertimbangkan unsur mahasiswa, dosen, lembaga pendidikan, pimpinan institusi, orangtua mahasiswa, gereja dan masyarakat. Pemahaman konsep kurikulum juga menjadi bagian penting dalam merumuskan kurikulum Pendidikan Agama Kristen. Hasil penelitian ini bukanlah konsep yang sudah paten. Masih perlu saran dan masukan dari berbagai pihak. Untuk itu peneliti memberikan rekomendasi kepada pegiat-pegiat literasi berikutnya untuk melakukan penelitian lebih lanjut. Peneliti sangat terbuka, jika ada peneliti lain yang akan membahas dan meneliti tema serupa untuk memperdalam penelitian tentang kurikulum Pendidikan Agama Kristen ini.

\section{Rujukan}

Bahri, Syamsul. "Pengembangan Kurikulum Dasar Dan Tujuannya." Jurnal Ilmiah Islam Futura 11, no. 1 (February 3, 2017): 15-34. Accessed June 10, 2020. https://jurnal.arraniry.ac.id/index.php/islamfutura/article/view/61.

Hasugian, Johanes Waldes. "Kurikulum Pendidikan Kristen bagi Orang Dewasa di Gereja." KURIOS (Jurnal Teologi dan Pendidikan Agama Kristen) 5, no. 1 (April 30, 2019): 36-53. Accessed June 10, 2020. http://www.sttpb.ac.id/ejournal/index.php/kurios/article/view/96.

Hutapea, Rinto Hasiholan. "Evaluasi Pembelajaran Pendidikan Agama Kristen Pada Kurikulum 2013." Jurnal Ilmiah Religiosity Entity Humanity (JIREH) 1, no. 1 (June 18, 2019): 18-30. Accessed June 10, 2020. https://ojsjireh.org/index.php/jireh/article/view/10.

Manuain, Leryani Mince Maria, Ferdinant Alexander, and Marsi Bombongan Rantesalu. "Pengaruh Model Pembelajaran Jigsaw Terhadap Peningkatan Hasil Belajar Sejarah Pendidikan Agama Kristen." Ciencias : Jurnal Penelitian dan Pengembangan Pendidikan1, no. 1 (July 27, 2018): 1-12. Accessed June 10, 2020. https:// ejournal.upg45ntt.ac.id/ciencias/article/view/9.

N, Sudirman. Ilmu Pendidikan. Bandung: Remadaja Karya, 1987.

Nasbi, Ibrahim. "MANAJEMEN KURIKULUM: Sebuah Kajian Teoritis." Idaarah: Jurnal Manajemen Pendidikan 1, no. 2 (December 18, 2017). Accessed June 10, 2020. http://journal.uin-alauddin.ac.id/index.php/idaarah/article/view/4274.

Nilamsari, Natalina. "Memahami Studi Dokumen Dalam Penelitian Kualitatif." Wacana XII, 
no. 2 (June 2014): 177-181. Accessed June 11, 2020.

http:/ fisip.untirta.ac.id/teguh/?p=16/.

Nuhamara, Daniel. Pembimbing Pendisikan Agama Kristen. Bandung: Jurnal Info Media, 2002.

Nurgiyantoro, Burhan. Dasar-Dasar Pengembangan Kurikulum Sekolah. Yogyakarta: BPFE, 1998.

Purnami I. Subekti, Sri. Kurikulum. Jakarta: Guna Widia, 1995.

Rantesalu, Marsi Bombongan. Guru Pendidikan Agama Kristen Sebagai Pelopor Revolusi Mental. Preprint. AgriXiv, October 14, 2019. Accessed January 21, 2020. https://osf.io/576qt.

Saifuddin, Ahmad. "Eksistensi Kurikulum Pesantren Dan Kebijakan Pendidikan." Jurnal Pendidikan Agama Islam (Journal of Islamic Education Studies) 3, no. 1 (2015): 207-234.

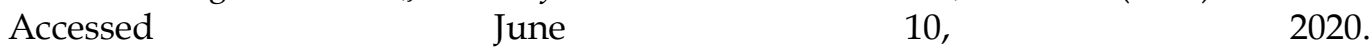
http://jurnalpai.uinsby.ac.id/index.php/jurnalpai/article/view/45.

Sairin, Weinata. Partisipasi Kristen Dalam Pembangunan Pendidikan Di Indonesia. Jakarta: BPK Gunung Mulia, 1998.

Sidjabat, Binsen Samuel. "Kerangka Kurikulum Pendidikan Agama Kristen Berbasis Karakter di Perguruan Tinggi." Jurnal Jaffray 17, no. 1 (April 5, 2019): 73-90. Accessed June 10, 2020. https://ojs.sttjaffray.ac.id/JJV71/article/view/314.

Sidjabat, B.S. Menjadi Guru Profesional Sebuah Presfektif Kristen. Bandung: Kalam Hidup, 2000.

Slameto. Proses Belajar Mengajar Dalam Sistem Kredit Semester. Jakarta: Bumi Aksara, 1991.

Soetopo, Hendyat, and Wasti Soemanto. Pembinaan Dan Pembangunan Kurikulum. Jakarta: Bina Aksara, 1986.

Sukmadinata, Nana Syaodih. Pengembangan Kurikulum Teori Dan Praktek. Bandung: Remaja Rosdakarya, 2000.

Tari, Ezra, and Rinto Hasiholan Hutapea. "Peran Guru Dalam Pengembangan Peserta Didik Di Era Digital." Kharisma: Jurnal Ilmiah Teologi 1, no. 1 (June 3, 2020): 1-13. Accessed June 11, 2020. http://jurnalsttkharisma.ac.id/index.php/Kharis/.

Uzer Usman, Moh. Menjadi Guru Profesional. Bandung: Remaja Rosdakarya, 1991. 